\title{
HUBUNGAN PERBANDINGAN TOTAL NITROGEN DAN TOTAL FOSFOR DENGAN KELIMPAHAN CHRYSOPHYTA DI PERAIRAN WADUK PANGLIMA BESAR SOEDIRMAN, BANJARNEGARA
}

\author{
FARALEngGi Dimar Maulita Putri, Endang Widyastuti, Christiani
}

Fakultas Biologi, Universitas Jenderal Soedirman, Jalan dr. Suparno 63 Purwokerto 53122

A B S T R A C T

Nitrogen $(\mathrm{N})$ and phosphorus $(\mathrm{P})$ affect the growth of phytoplankton in the waters. Nitrogen is an important part in forming protein in organisms, while phosphorus is the most essential element for growth and contributes in protein formation and cell metabolism in organisms. The activities from the catchment area that enter into the P.B Soedirman Reservoir can affect both concentration of N and P. The comparison total nitrogen (TN) and total phosphorus (TP) is the limiting factor to affect the growth of phytoplankton. Chrysophyta is one of division from phytoplankton that has function as an important component in the food chain and become as natural feed for fish. This research showed the abundance of Chrysophyta, relations of TN with the abundance of Chrysophyta; TP with the abundance of Chrysophyta; TN/TP with the abundance of Chrysophyta; TN, TP, TN/TP with the abundance Chrysophyta in the P.B Soedirman Reservoir, Banjarnegara Regency. This research used survey method with purposive sampling technique on 7 observation stations with 3 repeating. The relation of TN/TP with the abundance of Chrysophyta were analyzed used correlation regression - correlation analyzis. The results of the research showed that total abundance Chrysophyta was between 339-9570 ind/l, relation between TN/TP with the abundance of Chrysophyta with the degree was weak to very strong correlation. The most affection correlation was shown by of TN, TP, TN/TP collectively with the abundance of Chrysophyta with coefficient value (r) of 0,890 with the strength of the relation of 79,3\%. The regression analysis of TN, TP, TN/TP collectively with the abundance of Chrysophyta was shown by the equation Y= $-80987,801-$ $8499,931 \mathrm{TN}+1,684 \mathrm{TP}+406,373 \mathrm{TN} / \mathrm{TP}$.

KEY WORDS: TN/TP, abundance, Chrysophyta, correlation, Panglima Besar Soedirman Reservoir

Penulis korespondensi: FARALENGGI DIMAR MAULITA PUTRI | email: endang.widyastuti@yahoo.com

\section{PENDAH U L U A N}

Nutrien adalah unsur atau senyawa kimia yang digunakan untuk metabolisme atau proses fisiologi organisme. Nutrien di perairan terdapat dalam bentuk makro maupun mikro. Nutrien dalam bentuk makro terdiri dari: $\mathrm{C}, \mathrm{H}, \mathrm{O}, \mathrm{N}, \mathrm{S}, \mathrm{P}, \mathrm{K}, \mathrm{Mg}, \mathrm{Ca}, \mathrm{Na}$, dan $\mathrm{Cl}$, sedangkan yang termasuk dalam bentuk mikro terdiri dari Fe, Co, Zu, B, Si, Mn, dan Cu (Bold dan Wayne 1985 dalam Yazwar 2008). Nutrien yang paling dibutuhkan oleh organisme adalah unsur karbon, nitrogen, dan fosfor. Nutrien yang memiliki peran penting dalam pertumbuhan dan metabolisme fitoplankton adalah N dan P (Risamasu dan Prayitno, 2011). Keberadaan karbon jumlahnya sangat melimpah sebagai karbondioksida $\left(\mathrm{CO}_{2}\right)$, sehingga dianggap bahwa nitrogen dan fosfor yang paling dipertimbangkan. Nitrogen dan fosfor yang merupakan makro nutrien, keduanya mempunyai manfaat sebagai nutrien pembatas bagi pertumbuhan fitoplankton (Suthers dan Rissik, 2008).

Nitrogen merupakan kandungan dari protoplasma dan dibutuhkan fitoplankton untuk mensintesis protein. Nitrogen di perairan terdiri dari dua golongan yang berbeda bentuknya yaitu nitrogen organik dan nitrogen anorganik (Boyd, 1988). Effendi (2003) menyatakan bahwa, $\mathrm{N}$ anorganik berupa $\mathrm{N}-\mathrm{NO}_{3}, \mathrm{~N}-$ $\mathrm{NO}_{2}, \mathrm{~N}-\mathrm{NH}_{3}$ yang bersifat larut; dan $\mathrm{N}$ organik berupa partikulat yang tidak larut dalam air. Nitrogen tidak dapat dimanfaatkan secara langsung oleh tumbuhan akuatik dan harus mengalami fiksasi terlebih dahulu menjadi amonia $\left(\mathrm{NH}_{3}\right)$, amonium $\left(\mathrm{NH}_{4}{ }^{+}\right)$dan nitrat $\left(\mathrm{NO}_{3}^{-}\right)$.
Fosfor sangat penting untuk kehidupan organisme perairan karena berfungsi dalam penyimpanan dan transfer energi dalam sel dan berfungsi dalam sistem genetik (Cole, 1983). Fosfor di perairan dalam bentuk senyawa fosfat, yang terdiri atas fosfat terlarut dan fosfat partikulat. Fosfat terlarut terbagi atas fosfat organik dan fosfat anorganik yang terdiri dari ortofosfat dan polifosfat (Rumhayati, 2010).

Perbandingan Total Nitrogen dan Total Fosfor dapat mempengaruhi pertumbuhan fitoplankton di perairan. TN/TP di perairan yang diperlukan untuk pertumbuhan fitoplankton berkisar antara $10: 1$ sampai 20 : 1 (Grahame, 1987). Sulastri et al. (2007) menyatakan bahwa pada umumnya bila nilai rasio total $\mathrm{N}$ dan total $\mathrm{P}<12$ mengindikasikan bahwa nitrogen merupakan faktor pembatas pertumbuhan fitoplankton sedangkan rasio total $\mathrm{N}$ dan total $\mathrm{P}>12$ mengindikasikan bahwa fosfor merupakan faktor pembatas pertumbuhan fitoplankton. Dengan demikian konsentrasi $\mathrm{N}$ dan $\mathrm{P}$ di suatu perairan akan berpengaruh terhadap kelimpahan fitoplankton di perairan.

Chrysophyta merupakan fitoplankton yang mempunyai peranan penting di perairan tawar. Chrysophyta memiliki pigmen warna yang terdiri atas karoten dan xantofil yang berwarna kuning (Bold dan Wayne 1985 dalam Yazwar 2008). Chrysophyta mempunyai ciri-ciri antara lain berflagel tidak sama panjang dan tidak selalu sama bentuknya (Heterokontae), dinding sel diperkuat dengan bahan silika dan berpori (Davis, 1955).

Davis (1955) menyatakan bahwa Chrysophyta mempunyai pori-pori dengan bentuk yang terdiri dari 
2 bagian yaitu tutup (epiteka) dan wadah (hipoteka) yang mudah membuka sehingga memudahkan ikan untuk mencerna isi sel dengan bantuan enzim pencernaan. Chrysophyta biasanya melimpah di perairan yang relatif tenang seperti danau dan waduk.

Waduk Panglima Besar Soedirman (P.B Soedirman) terletak di dua kecamatan yaitu Kecamatan Bawang dan Kecamatan Wanadadi, Kabupaten Banjarnegara. Tepatnya pada 707' LS 7030' LS dan 109³1' BT - 109'8' BT, dan terletak pada ketinggian $239 \mathrm{dpl}$. Waduk P.B Soedirman mempunyai luas genangan sebesar 8.415.875 $\mathrm{m}^{2}$ dengan kapasitas sebesar 141.247.087 $\mathrm{m}^{3}$. Fungsi Waduk P.B Soedirman sebagai Pembangkit Listrik Tenaga Air (PLTA), irigasi, perikanan, pariwisata, dan pertanian (Widyastuti, 2005).

Kondisi lingkungan di daerah tangkapan air (DTA) yang masuk ke perairan Waduk P.B Soedirman yang dinamis dapat menyebabkan perubahan pada total N/P. Dengan demikian perlu dilakukan penelitian hubungan perbandingan total nitrogen dan total fosfor dengan kelimpahan Chrysophyta di Waduk P.B Soedirman.

Tujuan penelitian ini adalah untuk mengetahui : kelimpahan Chrysophyta; hubungan TN dengan kelimpahan Chrysophyta; TP dengan kelimpahan Chrysophyta; TN/TP dengan kelimpahan Chrysophyta; TN, TP, TN/TP dengan kelimpahan Chrysophyta di perairan Waduk P.B Soedirman, Kabupaten Banjarnegara.

\section{MET O DE}

Penelitian dilaksanakan di perairan Waduk P.B Soedirman, Kabupaten Banjarnegara, Jawa Tengah; Laboratorium Lingkungan dan Laboratoriun Biologi Akuatik Fakultas Biologi Universitas Jenderal Soedirman Purwokerto selama bulan Mei hingga September 2012.

Penelitian ini dilaksanakan dengan menggunakan metode survei. Teknik pengambilan sampel dilakukan secara purposive sampling pada 7 stasiun penelitian yang ditentukan berdasarkan rona lingkungan yaitu stasiun I, II, III adalah daerah inlet; stasiun IV daerah tengah; stasiun V daerah dermaga waduk; stasiun VI daerah outlet dan stasiun VII daerah karamba jaring apung (Gambar 1). Pengambilan sampel diulang sebanyak tiga kali dengan interval waktu 4 minggu. Variabel yang diamati meliputi variabel tergantung dan variabel bebas. Variabel tergantung yaitu kelimpahan Chrysophyta dan variabel bebasnya yaitu Total Nitrogen dan Total Fosfor. Parameter fisika dan kimia lain yang di diukur adalah suhu, penetrasi cahaya, kedalaman, $\mathrm{pH}$, TSS, TDS, $\mathrm{O}_{2}$ terlarut, $\mathrm{CO}_{2}$ bebas, $\mathrm{BOD}_{5}$, silika.

Sampel air permukaan diambil sebanyak 100 liter pada setiap stasiun dan disaring menggunakan plankton net no. 25. Sampel air dalam botol penampung plankton net dipindahkan ke dalam botol sampel lalu diberi larutan formalin $40 \%$ hingga kandungannya menjadi $4 \%$. Kemudian diberi lugol sebanyak 3 tetes.

Indentifikasi plankton menggunakan buku Thompsom (1966), Shirota (1966) dan Sachlan (1982). Perhitungan jumlah spesies mengunakan rumus modifikasi dari Lackey Drop Microtranset Counting (APHA, 1985) yaitu:

$$
\mathrm{F} \times \mathrm{N}
$$

$$
\mathrm{F}=\frac{\mathrm{Q} 1}{\mathrm{Q} 2} \times \frac{\mathrm{V} 1}{\mathrm{~V} 2} \times \frac{1}{\mathrm{P}} \times \frac{1}{\mathrm{~W}}
$$

Keterangan :

$\mathrm{Q} 1$ = Luas gelas penutup $18 \times 18\left(324 \mathrm{~mm}^{2}\right)$

$\mathrm{Q} 2$ = Luas lapang pandang $\left(1,11279 \mathrm{~mm}^{2}\right)$

$\mathrm{V} 1$ = Volume air dalam botol sampel $(113 \mathrm{ml})$

$\mathrm{V} 2$ = Volume air di bawah gelas penutup $(0,045 \mathrm{ml})$

$\mathrm{P}=$ Jumlah lapang pandang yang diamati (25 kali)

$\mathrm{W}$ = Volume air yang disaring (100 l)

$\mathrm{N}$ = Jumlah plankton yang ditemukan

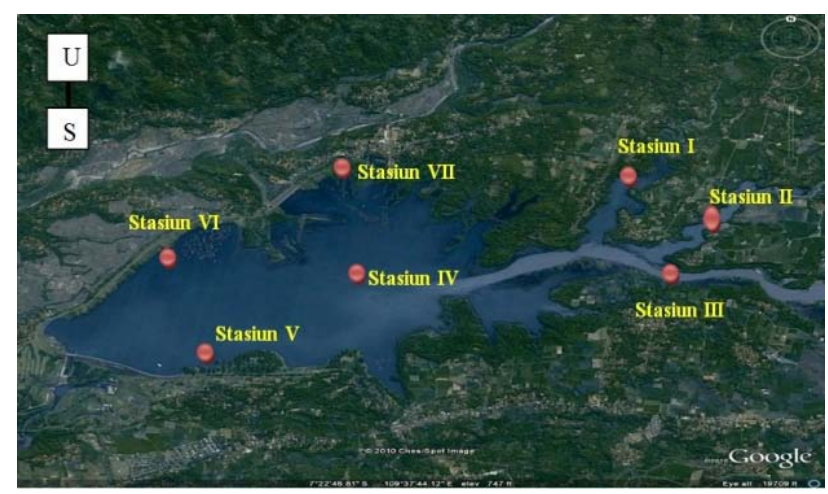

Gambar 1. Lokasi Stasiun

Konsentrasi total nitrogen diukur menggunakan metode Mikrokjeldahl dari APHA (1992). Konsentrasi total fosfor di ukur menggunakan metode Asam Askorbat dari APHA (1992). Hubungan TN dengan kelimpahan Chrysophyta; TP dengan kelimpahan Chrysophyta; TN/TP dengan Chrysophyta; TN, TP, TN/TP dengan Chrysophyta dianalisis menggunakan analisis regresi - korelasi. Analisis data menggunakan program komputer SPSS versi 16 for Windows. Interpetasi terhadap koefisien korelasi yang ditunjukkan pada Tabel 1.

Tabel 1. Pedoman untuk memberikan interpretasi terhadap koefisien korelasi.

\begin{tabular}{cc}
\hline Interval koefisien & Tingkat hubungan \\
\hline $0,00-0,199$ & Sangat lemah \\
$0,20-0,399$ & Lemah \\
$0,40-0,599$ & Sedang \\
$0,60-0,799$ & Kuat \\
$0,80-1,000$ & Sangat kuat \\
\hline
\end{tabular}

Sumber : Arikunto (2006)

\section{HASIL DAN PEMBAHASAN}

Konsentrasi TN, TP, TN/TP yang didapatkan selama penelitian di perairan Waduk P.B Soedirman ditunjukkan pada Tabel 2. Hasil pengukuran konsentrasi TN yang didapat berkisar antara 6,774$11,702 \mathrm{mg} / \mathrm{l}$. Hasil pengukuran konsentrasi TP yang didapat berkisar antara 0,024-0,063 mg/l. Hasil pengukuran TN/TP yang didapat berkisar antara 185,746-335,178 unit.

Sumber $\mathrm{N}$ di perairan Waduk P.B Soedirman diperkirakan berasal dari aktivitas pertanian dan limbah domestik di daerah tangkapan air (DTA) yang masuk ke waduk melalui Sungai Lumajang dan Sungai Serayu. Hasil penelitian diperoleh kadar total nitrogen tertinggi yaitu inlet Sungai Serayu (Stasiun III) sebesar 11,702 mg/l dan inlet Sungai Lumajang (Stasiun I) sebesar 10,452 $\mathrm{mg} / \mathrm{l}$ yang lebih tinggi dibandingkan stasiun yang lainnya. Menurut 
Departemen Kehutanan (2009), DTA adalah suatu wilayah daratan yang merupakan satu kesatuan dengan sungai dan anak-anak sungainya, yang berfungsi menampung, menyimpan dan mengalirkan air yang berasal dari curah hujan ke danau atau ke laut secara alami, yang batas di darat merupakan pemisah topografis (punggung-punggung bukit) dan batas di laut sampai dengan daerah perairan yang masih terpengaruh aktivitas daratan.

Tabel 2. Konsentrasi TN, TP dan TN/TN yang diperoleh selama penelitian di Waduk P.B Soedirman, Banjarnegara

\begin{tabular}{cccc}
\hline \multirow{2}{*}{ Stasiun } & \multicolumn{2}{c}{ Parameter } & \multirow{2}{*}{ T N/TP (unit) } \\
\cline { 2 - 3 } & TN (mg/l) & TP (mg/l) & \\
\hline I & 10,452 & 0,039 & 268,000 \\
II & 7,940 & 0,048 & 165,417 \\
III & 11,702 & 0,064 & 182,844 \\
IV & 7,685 & 0,034 & 226,029 \\
V & 6,774 & 0,029 & 233,586 \\
VI & 9,385 & 0,041 & 228,902 \\
VII & 7,934 & 0,035 & 226,686 \\
\hline
\end{tabular}

Sumber nitrogen dari aktifitas pertanian yang masuk ke perairan berasal dari penggunaan pupuk. Pupuk yang digunakan pada lahan pertanian masuk ke aliran sungai melalui sistem drainase (Frame dan Reiter, 2013). Menurut Suwarno (2009), pupuk N yang biasa digunakan petani umumnya adalah pupuk urea dan ZA. Saragih et al. (2013) menambahkan, konsentrasi $\mathrm{N}$ yang ada pada pupuk urea sebesar 46\%. Windarti et al. (2011), menyatakan bahwa konsentrasi $\mathrm{N}$ yang terdapat pada pupuk ZA sebesar $21 \%$.

Selain pupuk sumber $\mathrm{N}$ dari aktivitas pertanian juga berasal dari limbah pertanian yang mengalami dekomposisi contohnya jerami. Ekawati (2005), menyatakan bahwa kandungan $\mathrm{N}$ dalam jerami sebesar 0,8-1,0\%. Sumber $N$ selain berasal dari aktifitas pertanian juga dapat berasal dari limbah domestik. Nurmayanti (2002) menyatakan bahwa, limbah domestik adalah semua bahan limbah yang berasal dari kamar mandi, kakus, dapur, tempat cuci pakaian dan cuci peralatan rumah tangga. Menurut Vinneras et al. (2006), feses manusia mengandung 1020\% N sedangkan Mara dan Crairncross (1994) menyatakan bahwa urin manusia mengandung 15$19 \% \mathrm{~N}$.

Sumber nitrogen di perairan Waduk P.B Soedirman juga dimungkinkan berasal dari budidaya ikan dalam karamba jaring apung (KJA). Price dan Morris (2013), menyatakan bahwa KJA memberikan kontribusi nitrogen di perairan yaitu dalam bentuk sisa pakan yang tidak dimakan ikan, feses ikan, dan limbah metabolik ikan berupa amonia juga urea. Pakan yang diberikan kepada ikan mengandung sekitar 68\%-86\% N dilepaskan ke lingkungan perairan dan sisanya dimakan oleh ikan (Price dan Morris, 2013). Sumber P di perairan Waduk P.B Soediman diperkirakan berasal dari aktivitas pertanian dan limbah domestik di daerah tangkapan air (DTA) yang masuk ke waduk melalui Sungai Kandangwangi dan Sungai Serayu. Hasil penelitian diperoleh konsentrasi $\mathrm{P}$ tertinggi berasal dari inlet Sungai Serayu (Stasiun III) sebesar 0,064 mg/l dan pada inlet Sungai Kandangwangi (Stasiun II) sebesar 0,048 mg/l. Sumber masuknya $\mathrm{P}$ di perairan dari aktivitas pertanian berasal dari penggunaan pupuk di lahan pertanian. Suwarno (2009) menyatakan bahwa pupuk $\mathrm{P}$ yang sering digunakan petani pada umumnya adalah pupuk SP 36 karena mudah didapatkan di pasaran. Menurut Kasno (2009), konsentrasi P dalam pupuk SP 36 sebesar 36\%. Masuknya P ke perairan juga berasal dari limbah domestik (permukiman) yaitu feses, urin, dan detergen. Menurut Vinneras et al. (2006), konsentrasi P yang ada pada feses sebesar 20 - 50\%, dan Jonsson (1997) menyatakan konsentrasi P pada urin sebesar 65\%. Menurut Liong dan Asmawati (2002), detergen adalah bahan pembersih yang mengandung senyawa petrokimia atau surfaktan lainnya. Surfaktan merupakan bahan pembersih utama yang terdapat dalam detergen.

Dhakite et al. (2011), menambahkan komposisi detergen umumnya adalah surfaktan, zat pembangun (builders), acid slurry, sodium karbonat, sodium sulfat, garam, sodium tripolifosfat, sodium lauril eter sulfat, EDTA, zat pemutih, sodium silikat, sodium lauril sulfat, dan parfum. Yangxin et al. (2008), menyatakan bahwa builders merupakan komponen yang berfungsi meningkatkan efisiensi kinerja surfaktan. Fosfat merupakan salah satu builders dalam formulasi detergen. Sodium tripolifospat (STPP) merupakan salah satu contoh dari fosfat yang paling penting dalam pembuatan detergen bubuk. Secara umum fungsi sodium tripolifospat adalah meningkatkan kekuatan menghilangkan dan mengendapkan kotoran dan membantu detergen memiliki struktur yang baik.

Selain aktivitas pertanian dan limbah domestik, sumber fosfor di perairan Waduk P.B Soedirman dimungkinkan juga berasal dari budidaya ikan dalam karamba jaring apung (KJA). Price dan Morris (2013), menyatakan sumber fosfor di KJA berasal dari sisa pakan yang tidak termakan oleh ikan, feses ikan, dan limbah metabolik ikan dalam bentuk fosfat. Pakan yang diberikan kepada ikan sekitar 71,4\% $\mathrm{P}$ dilepaskan ke lingkungan perairan dan sisanya dimakan oleh ikan (Price dan Morris, 2013).

Hasil penelitian menunjukkan Chrysophyta yang didapatkan pada penelitian di perairan Waduk P.B Soedirman sebanyak 13 spesies dengan total kelimpahan berkisar antara 339-9570 ind/l (Tabel 3). Data kelimpahan Chrysophyta pada Tabel 3 menunjukkan bahwa Nitzschia seriata memiliki kelimpahan relatif paling tinggi sebesar 28,67\%, diikuti oleh Synedra acus dengan 26,14\%, Navicula brachysira dengan 21,33\%, Synedra ulna berkisar antara dengan $8,72 \%$, dan Nitzschia curvula dengan $4,58 \%$.

Nitzschia seriata ditemukan melimpah disebabkan oleh sifatnya yang kosmopolit. Hal ini sesuai dengan pendapat Scheggia et al. (2008), yang menyatakan bahwa genus Nitzschia merupakan salah satu fitoplankton yang kosmopolit dan distribusinya dapat 
ditemukan di air tawar, air laut, juga mempunyai keragaman morfologi yang beragam. Spesies dari Nitzschia lain yang ditemukan di perairan Waduk P.B Soedirman, Banjarnegara adalah Nitzschia artinagtroides dengan kelimpahan relatif sebesar 1,15\%, Nitzschia curvula (4,58\%), dan Nitzschia pedifica $(0,46 \%)$, sehingga total kelimpahan relatif genus Nitzschia yang didapat adalah $34,86 \%$.

Tabel 3. Kelimpahan Chrysophyta (ind/l) per stasiun di perairan Waduk P.B Soedirman

\begin{tabular}{|c|c|c|c|c|c|c|c|c|c|}
\hline \multirow{2}{*}{ Species } & \multicolumn{7}{|c|}{ Stasiun } & \multirow{2}{*}{$\begin{array}{r}\text { Jumlah } \\
\text { per } \\
\text { individu }\end{array}$} & \multirow[b]{2}{*}{ KR \% } \\
\hline & I & II & III & IV & $\mathrm{V}$ & VI & VII & & \\
\hline 1Amphipleura pellucida & 0 & 169 & 0 & 0 & 0 & 0 & 169 & 169 & 0,69 \\
\hline 2Asterionella formosa & 0 & 676 & 338 & 0 & 0 & 0 & 0 & 676 & 2,75 \\
\hline 3Brebissonia boeckli & 0 & 282 & 113 & 169 & 0 & 0 & 0 & 282 & 1,15 \\
\hline 4Chlamydomonas noctigama & 0 & 507 & 0 & 0 & 0 & 507 & 0 & 507 & 2,06 \\
\hline 5Chloromonas sp & 113 & 282 & 0 & 169 & 0 & 0 & 0 & 282 & 1,15 \\
\hline 6Navicula brachysira & 0 & 5235 & 0 & 169 & 0 & 2195 & 2871 & 5235 & 21,33 \\
\hline 7Nitzschia artinagtroides & 0 & 282 & 0 & 0 & 0 & 0 & 282 & 282 & 1,15 \\
\hline 8N. curvula & 0 & 1126 & 0 & 0 & 0 & 0 & 0 & 1126 & 4,58 \\
\hline 9N. pedifica & 0 & 113 & 113 & 0 & 0 & 0 & 0 & 113 & 0,46 \\
\hline $10 N$. seriata & 113 & 7037 & 338 & 507 & 2195 & 1013 & 2871 & 7037 & 28,67 \\
\hline 11Synedra acus & 0 & 6418 & 0 & 1858 & 1689 & 0 & 2195 & 6418 & 26,14 \\
\hline 12S. ulna & 113 & 2140 & 338 & 0 & 507 & 0 & 1182 & 2140 & 8,72 \\
\hline 13S. capitata & 0 & 282 & 113 & 0 & 0 & 169 & 0 & 282 & 1,15 \\
\hline Jumlah total (ind/l) & 339 & 2140 & 1353 & 2872 & 4391 & 3884 & 9570 & & \\
\hline
\end{tabular}

Kelimpahan relatif terbesar kedua ditunjukkan oleh Synedra acus dengan total kelimpahan 26,14\%. Spesies Synedra yang ditemukan di perairan Waduk P.B Soedirman adalah Synedra acus $(26,14 \%)$, Synedra alna (8,72\%), dan Synedra capitata (1,15\%), sehingga total kelimpahan genus Synedra yang didapatkan yaitu 36.01\%. Synedra merupakan fitoplankton dengan sebaran yang sangat luas. Wehr dan Sheath (2003) menyatakan bahwa genus Synedra dapat sangat melimpah pada danau oligotrofik, mesotrofik atau eutrofik pada waktu kapanpun.

Kelimpahan relatif terbesar ketiga ditunjukkan oleh Navicula brachysira dengan kelimpahan relatif sebesar 21,33\%. Ramirez dan Bicudo (2005) menambahkan, Navicula merupakan salah satu fitoplankton yang digunakan sebagai indikator perairan yang kaya unsur hara dan semakin tinggi nitrat di lingkungan akan dapat memicu pertumbuhan Navicula. Menurut Astuti et al. (2012), Navicula merupakan genera diatom yang potensial dikembangkan dan diperlukan sebagai pakan alami untuk budidaya baik larva udang maupun kekerangan. Hubungan TN; TP; TN/TP; dan TN, TP,TN/TP secara bersama dengan kelimpahan Chrysophyta ditunjukkan dengan nilai koefesien korelasi (Tabel 4).

Hasil analisis korelasi antara TN dengan kelimpahan Chrysophyta di perairan Waduk P.B
Soedirman ditunjukkan oleh nilai koefesien korelasi (r) sebesar 0,519 artinya hubungan yang didapatkan dari TN dengan kelimpahan Chrysophyta sedang. Menurut Arikunto (2006), nilai r diantara 0,40-0,599 artinya antar variabel memiliki korelasi sedang. Kehandalan hubungan antara TN dengan kelimpahan Chrysophyta ditunjukkan dengan nilai koefesien determinasi $\left(\mathrm{R}^{2}\right)$ sebesar $26,9 \%$.

Hasil analisis korelasi antara TP dengan kelimpahan Chrysophyta didapatkan nilai koefesien korelasi (r) sebesar 0,281 artinya hubungan yang didapatkan dari TP dengan kelimpahan Chrysophyta lemah. Menurut Arikunto (2006), jika nilai r diantara 0,20-0,399 antar variabel memiliki hubungan lemah. Kehandalan hubungan antara TP dengan kelimpahan Chrysophyta ditunjukkan dengan nilai koefesien determinasi $\left(\mathrm{R}^{2}\right)$ sebesar 7,9\%. Hasil analisis korelasi antara TN/TP dengan kelimpahan Chrysophyta ditunjukkan oleh nilai koefesien korelasi (r) sebesar 0,524 artinya hubungan yang didapatkan dari TN/TP dengan kelimpahan Chrysophyta sedang. Menurut Arikunto (2006), jika nilai r diantara 0,40-0,599 antar variabel memiliki hubungan sedang. Kehandalan hubungan antara TN/TP dengan kelimpahan Chrysophyta ditunjukkan dengan nilai koefesien determinasi $\left(\mathrm{R}^{2}\right)$ sebesar $27,5 \%$.

Tabel 4. Hasil analisis hubungan antara TN; TP; TN/TP; TN, TP, dan TN/TP dengan kelimpahan Chrysophyta.

\begin{tabular}{cccc}
\hline \multirow{2}{*}{ Parameter } & \multicolumn{3}{c}{ Hubungan } \\
\cline { 2 - 4 } & Koefisien korelasi (r) & Tingkat hubungan & Koefisien determinasi R ${ }^{2}$ ) \\
TN & 0,519 & Sedang & $26,9 \%$ \\
TP & 0,281 & Lemah & $7,9 \%$ \\
TN/TP & 0,524 & Sedang & $27,5 \%$ \\
TN, TP dan TN/TP & 0,890 & Sangat Kuat & $79,3 \%$ \\
\hline
\end{tabular}

Hasil analisis korelasi antara TN, TP, TN/TP secara bersama dengan kelimpahan Chrysophyta ditunjukkan oleh nilai koefesien korelasi (r) sebesar
0,890. Hubungan yang didapatkan dari TN, TP, TN/TP dengan kelimpahan Chrysophyta yang diperoleh sangat kuat. Menurut Arikunto (2006), jika nilai 
koefisien korelasi (r) sebesar 0,80-1,000 artinya antar variabel memiliki hubungan sangat kuat. Kehandalan TN, TP, TN/TP terhadap kelimpahan Chrysophyta ditunjukkan dengan nilai koefesien determinasi $\left(\mathrm{R}^{2}\right)$ sebesar 79,3\%.

Berdasarkan Tabel 4 hubungan TN; TP; rasio TN/TP; dan TN, TP, TN/TP dengan kelimpahan Chrysophyta yang mempunyai hubungan kuat adalah hubungan antara TN, TP, TN/TP secara bersama dengan kelimpahan Chrysophyta dengan $\mathrm{r}$ sebesar 0,890. Hubungan antara TN, TP, TN/TP secara bersama dengan kelimpahan Chrysophyta yang kuat dilanjutkan dengan analisis regresi. Hasil analisis regresi hubungan total $\mathrm{TN}, \mathrm{TP}, \mathrm{TN} / \mathrm{TP}$ secara bersama dengan kelimpahan Chrysophyta ditunjukkan oleh persamaan linear berganda $\mathrm{Y}=$-80987,8018499,931TN+1,684TP+406,373TN/TP

Persamaan yang diperoleh menjelaskan bahwa TN, TP, TN/TP secara bersama mempengaruhi kelimpahan Chrysophyta (Y) yaitu dimana setiap kenaikan 0,1 mg/l TN akan menurunkan kelimpahan Chrysophyta sebesar 8499,931 ind/l, dimana setiap kenaikan 0,1 mg/l TP akan menaikkan kelimpahan Chrysophyta sebesar 1,684 ind/l dan dimana setiap kenaikan 0,1 unit TN/TP akan menaikkan kelimpahan Chrysophyta sebesar 406,373 ind/l. Kehandalan hubungan antara TN, TP, TN/TP secara bersama ditunjukkan oleh nilai koefisien determinasi $\left(\mathrm{R}^{2}\right)$ sebesar 79,3\%. Hal ini menunjukkan bahwa kelimpahan Chrysophyta dipengaruhi oleh TN, TP, TN/TP secara bersama sebesar 79,3\% sisanya 20,7\% ditentukan oleh faktor fisika dan kimia perairan lainnya. Faktor pendukung lain yang mempengaruhi kelimpahan fitoplankton termasuk Chrysophyta adalah suhu, kedalaman, penetrasi cahaya, TSS, TDS, $\mathrm{pH}, \mathrm{O}_{2}$ terlarut, $\mathrm{CO}_{2}$ bebas, $\mathrm{BOD}$, dan silika.

Pengukuran suhu pada penelitian di perairan Waduk P.B Soedirman didapatkan suhu udara berkisar antara $26-29^{\circ} \mathrm{C}$. Suhu air bekisar antara 26,33-27,750 C. Effendi (2003), kisaran suhu optimal bagi pertumbuhan fitoplankton adalah $20^{\circ} \mathrm{C}-30^{\circ} \mathrm{C}$. Kondisi suhu di perairan Waduk P.B Soedirman masih baik untuk pertumbuhan fitoplankton.

Hasil pengukuran $\mathrm{pH}$ diperoleh berkisar antara 67. $\mathrm{pH}$ perairan Waduk P.B Soedirman ini masih dapat mendukung bagi kehidupan organisme akuatik yang ada di dalamnya termasuk fitoplankton. Arizuna et al. (2014), fitoplankton dapat hidup dalam suatu perairan yang mempunyai nilai $\mathrm{pH}$ yang netral dengan kisaran toleransi antara asam lemah sampai basa lemah. Penetrasi cahaya merupakan tingkat cahaya mampu menembus lapisan perairan. Hasil pengukuran penetrasi cahaya di perairan Waduk P.B Soedirman berkisar antara 31,92-88,50 cm. Menurut Asriyana dan Yuliana (2012), intensitas cahaya matahari yang masuk ke dalam badan perairan tertinggi terdapat di lapisan air teratas. Hasil penelitian didapatkan kedalaman waduk P.B Soedirman berkisar antara 1,3-8,17m.
Hasil pengukuran Total Suspended Solid (TSS) didapatkan berkisar antara 4 - 25 mg/l. Berdasarkan pengukuran nilai TSS yang di peroleh cukup rendah sehingga perairan P.B Soedirman cukup baik untuk budidaya perikanan. Menurut PP No. 82 tahun 2001, bahwa kisaran bahan tersuspensi sesuai dengan baku mutu kelas II untuk pariwisata, pembudidayaan ikan air tawar, peternakan dan air untuk pertanaman tidak boleh lebih dari $50 \mathrm{mg} / \mathrm{l}$. Hasil pengukuran Total Disolved Solid (TDS) di perairan Waduk P.B Soedirman didapatkan berkisar antara $91 \mathrm{mg} / \mathrm{l}$ - $136 \mathrm{mg} / \mathrm{l}$. Menurut PP No.82 Tahun 2001 bagi baku mutu kelas II, besarnya residu terlarut suatu perairan untuk sarana pariwisata, pembudidayaan ikan air tawar, peternakan dan air untuk pertanaman tidak boleh lebih dari $1000 \mathrm{mg} / \mathrm{l}$. Berdasarkan hal tersebut maka dapat dikatakan nilai TDS di perairan Waduk P.B Soedirman masih mendukung untuk kehidupan fitoplankton khususnya Chrysophyta.

Hasil pengukuran oksigen terlarut yang sebesar 4,3-5,5 mg/l. Oksigen terlarut perairan Waduk P.B Soedirman dapat mendukung kehidupan fitoplankton. Boyd (1988) menyatakan, plankton dapat tumbuh baik pada kondisi perairan dengan nilai oksigen terlarut $>5 \mathrm{mg} / \mathrm{l}$. Hasil pengukuran $\mathrm{CO}_{2}$ bebas yang didapatkan dari hasil penelitian di perairan Waduk P.B Soedirman sebesar 0,61 - 4,91 mg/l. Effendi (2003), menyatakan bahwa perairan yang diperuntukan bagi kepentingan perikanan sebaiknya memiliki ketersediaan karbondioksida bebas $<5 \mathrm{mg} / \mathrm{l}$. Oleh karena itu, konsentrasi $\mathrm{CO}_{2}$ bebas di perairan Waduk P.B Soedirman masih baik untuk mendukung kehidupan organisme di dalamnya termasuk fitoplankton. Hasil pengukuran BOD yang didapatkan dari hasil penelitian berkisar antara 1,79 mg/l - 4,07 $\mathrm{mg} / \mathrm{l}$, hal ini menunjukkan BOD Waduk P.B Soedirman masih baik untuk pertumbuhan fitoplankton. Menurut Effendi (2003), perairan yang memiliki BOD >10 mg/l dapat mengindikasikan air tercemar dan hal ini didukung oleh PP No.82 Tahun 2001 yang menyatakan bahwa besarnya BOD5 untuk mutu kelas II yaitu tidak boleh lebih dari $3 \mathrm{mg} / \mathrm{l}$.

Konsentrasi silika yang didapatkan pada saat penelitian berkisar antara 21,31- 27,12 mg/l. Silika $\left(\mathrm{SiO}_{2}\right)$ merupakan partikel tersuspensi di perairan dalam bentuk silisic acid atau ion silikat, pada perairan alami silika berasal dari degradasi batuan yang mengandung silika (APHA, 1992). Lee (2008) menyatakan bahwa silika merupakan unsur kedua yang paling melimpah di kerak bumi tetapi sulit untuk larut dalam air.

\section{KE S I M P U L A N}

Berdasarkan dari hasil dan pembahasan, maka dapat diambil kesimpulan bahwa hubungan TN/TP dengan kelimpahan Chrysophyta didapatkan hubungan kuat pada hubungan TN, TP, TN/TP secara bersama dengan kelimpahan Chrysophyta dengan kehandalan $79,3 \%$ dan ditunjukan dengan persamaan regresi $\mathrm{Y}=$ $-80987,801-8499,931 \mathrm{TN}+1,684 \mathrm{TP}+$ 
406,373TN/TP. Hubungan TN/TP Hubungan TN/TP dengan kelimpahan Chrysophyta ditunjukkan dengan rincian sebagai berikut:

Kelimpahan Chrysophyta di perairan Waduk P.B Soedirman diperoleh sebanyak 13 spesies. Kelimpahan relatif yang tertinggi yaitu Nitzschia seriata $(28,67 \%)$, diikuti Synedra acus $(26,14 \%)$, dan Navicula brachysira $(21,33 \%)$.

Hubungan TN dengan kelimpahan Chrysophyta di perairan Waduk P.B Soedirman sedang dengan kehandalan hubungan 26,9\%. Hubungan TP dengan kelimpahan Chrysophyta di perairan Waduk P.B Soedirman lemah dengan kehandalan hubungan 7,9\%. Hubungan TN/TP dengan kelimpahan Chrysophyta di perairan Waduk P.B Soedirman sedang dengan kehandalan hubungan $27,5 \%$.

Hubungan TN, TP, TN/TP secara bersama dengan kelimpahan Chrysophyta di perairan Waduk P.B Soedirman sangat kuat dan ditunjukkan dengan persamaan $\mathrm{Y}=-80987,801-8499,931 \mathrm{TN}+1,684 \mathrm{TP}+$ $406,373 \mathrm{TN} / \mathrm{TP}$. Kehandalan hubungan antara TN, TP, TN/TP secara bersama sebesar $79,3 \%$, sisanya $20,7 \%$ ditentukkan oleh faktor fisika kimia perairan lainnya.

\section{DAFT AR REFERENSI}

APHA, AWWA, and WEF. 1992. Standard methods for the examination of water and waste water. New York: American Public Health Association, American Water Work Association and Water Environmental Federation Inc.

Arikunto S. 2006. Prosedur penelitian suatu pendekatan praktik. Jakarta: Rineka Cipta.

Arizuna M, Suprapto D, Muskananfola MR. 2014. kandungan nitrat dan fosfat dalam air pori sedimen di sungai dan muara Sungai Wedung Demak. Diponegoro Journal of Maquares. 3(1): 7-16.

Asriyana, Yuliana. 2012. Produktivitas perairan. Jakarta: Bumi Aksara.

Astuti RP, Imanto PT, Sumiarsa GS. 2012. kelimpahan beberapa jenis mikroalga diatom perairan Pulau Gumilamo-Magaliho, Halmahera Utara. Jurnal Ilmu dan Teknologi Kelautan Tropis. 4(1): 97-106.

Boyd CE. 1988. Water quality in warmwater fish ponds. 4th ed. Alabama: Auburn Agricultured Experiment Stasion.

Cole GA. 1983. Text Book of Limnology. 3r ed. Missouri: C.V. Mosby Company.

Davis CC. 1955. The Marine and Fresh Water Plankton. Chicago: Michigan State University Press.

Dhakite PA, Deshpande AD, Gogte BB, Phate BW. 2011. Testing ecofriendly detergent powder and liquid detergent. International journal of Research in Pharmacy and Chemistry. 1(3): 2231-2781.

Direktorat Jenderal Reboisasi Lahan dan Perhutanan Sosial. 2009. Penyiapan dasar untuk penyusunan RTL-RLKT Sub DTA Cimanuk Hulu. Jawa Barat: Balai Rehabilitasi Lahan dan Konservasi Tanah, Departemen Kehutanan.

Effendi H. 2003. telaah kualitas air bagi pengelolaan sumber daya dan lingkungan perairan. Yogyakarta: Kanisius.

Ekawati I. 2005. Mineralisasi nitrogen pada pengomposan jerami. Jurnal AGRI-TEK. 5(2): 1-3.

Frame H, Reiter MS. 2013. Enhanced efficiency fertilizer materials: nitrogen stabilizer. Petersburg: Virginia Polytechnic Institute and State University.

Grahame J. 1987. Plankton and fisheries. London: Edward Arnold.

Jonsson H. 1997. Assesment of sanitation systems and reuse of urine. ecological alternatives in sanitation. proceedings from sida sanitation workshop. Publications on Water Resources nro 9; 1997 August 607; Balingsholm, Sweden; p. 11-22.
Kasno A. 2009. Jenis dan sifat pupuk anorganik. Bogor: Balai Penelitian Tanah.

Lee RE. 2008. Phycology. Cambridge: Cambridge University Press.

Liong S, Asmawati A. 2002. Analisis residu detergen anionik Alkil Sulfonat Linear (ASL) di sekitar perairan Pantai Losari Makassar Sulawesi Selatan. Marina Chimica Acta. 2(1): 15-17.

Mara D, Craincross S. 1994. pemanfaatan air limbah dan ekskreta: patokan untuk perlindungan kesehatan masyarakat. Bandung.: Universitas Udayana dan ITB.

Nurmayanti. 2002. Kontribusi limbah domestik terhadap kualitas air Kaligarang Semarang [tesis]. Universitas GajahmadaYogyakarta.

Peraturan Pemerintah Republik Indonesia Nomor 82 Tahun 2001 Tentang Pengelolaan Kualitas Air dan Pengendalian Pencemaran air. 2001. Sekertariat Negara Republik Indonesia.

Price CS, Morris JA. 2013. Marine cage culture and the environment: twenty-first century science informing a sustainable industry. Pivers Island Rd: NOAA Technical Memorandum NOS NCCOS.

Ramirez JJ, Bicudo C.EM. 2005. Diurnal and spatial (vertical) dynamics of nutrient $(\mathrm{N}, \mathrm{P}, \mathrm{Si})$ in four sampling days (summer, fall, winter and spring) in a tropical shallow reservoir and their relationships with the phytoplankton community. Braz. J. Biol. 65(1):141-157.

Risamasu FJL, Prayitno HB. 2011. Kajian zat hara fosfat, nitrit, nitrat dan silikat di perairan Matasisi, Kalimantan Selatan. Ilmu Kelautan. 16(3): 135-142.

Rumhayati B. 2010. Studi senyawa fosfat dalam sedimen dan air menggunakan teknik diffusive gradien in thin films. Jurnal Ilmu Dasar. 11(2):160-166.

Sachlan M. 1982. Planktonologi. Semarang: Fakultas Peternakan dan Perikanan, Universitas Diponegoro.

Saragih D, Hamim H, Nurmauli N. 2013. Pengaruh dosis dan waktu aplikasi pupuk urea dalam meningkatkan pertumbuhan dan hasil jagung Pioneer 27. J. Agrotek Tropik. 1(1): 50-54.

Scheggia SQ, Garces E, Sampedro N, Lenning KV, Flo E, Andre K, Fortuno JM, Camp J. 2008. Identification and characterisation of the dominant pseudo-nitzchia spesies (Bacillariophyceae) along the NE Spanish Coast (Catalonia, NW Mediterranean). Scientia Marina. 72(2): 343-359.

Shirota A. 1966. The plankton of South Vietnam. Tokyo: Technical Cooperation.

Sulastri, Meutia AA, Suryono T. 2007. Komposisi fitoplankton dan peluang blooming Microcystis aeruginosa di Waduk Karangkates. Jawa Timur. Oseanologi dan Limnologi Indonesia.

Suther IM, Rissik D. 2008. Plankton: a guide to their ecology and monitoring for water quality. Collingwood, CSIRO.

Suwarno D. 2009. Potensi dan masalah sampah di jawa tengah (studi kasus pengadaan pupuk organik yang berkelanjutan). Simposium Nasional RAPI VIII 2009; Semarang.

Thompson RH. 1959. Algae. In Edmonsond, WT, editor. 1959. Freshwater Biology 2nd ed. New York: John Willey and Sons, Inc.

Vinneras B. 2006. Faecal separation and urine diversion for nutrient management of household biodegradable waste and wastewater [thesis]. Uppsala: Swedish University of Agricultural Sciences.

Wehr JD, Sheath RG. 2003. Freshwater algae of North America: ecology and classification. New York: Academic Press.

Widyastuti, E. 2005. Model pengelolaan berkelanjutan budidaya ikan dalam keramba jaring apung di waduk (studi kasus di perairan waduk P.B. Soedirman) [disertasi]. Sekolah Pasca Sarjana Institut Pertanian Bogor-Bogor.

Windarti T, Wijayanti, Najib M. 2011. Analisis kecenderungan kebutuhan pupuk urea dan ZA di Kabupaten Kutai Kartanegara. EPP. 8(1): 24-29.

Yangxin Yu, Jin Z, Bayly AE. 2008. Development of surfactants and builders in detergent formulations. Chinese Journal of Chemical Engineering. 16(4): 517-527.

Yazwar. 2008. Keanekaragaman plankton dan keterkaitannya dengan kualitas air di Parapat Danau Toba [tesis]. Universitas Sumatera Utara-Medan. 